\title{
Partisanship, Public Opinion, and Redistricting
}

\section{Citation}

Fougere, Joshua, Stephen Daniel Ansolabehere, and Nathaniel Persily. 2010. Partisanship, public opinion, and redistricting. Election Law Journal: Rules, Politics, and Policy 9(4): 325-347.

\section{Published Version}

doi:10.1089/elj.2010.9405

\section{Permanent link}

http://nrs.harvard.edu/urn-3:HUL.InstRepos:10136321

\section{Terms of Use}

This article was downloaded from Harvard University's DASH repository, and is made available under the terms and conditions applicable to Other Posted Material, as set forth at http:// nrs.harvard.edu/urn-3:HUL.InstRepos:dash.current.terms-of-use\#LAA

\section{Share Your Story}

The Harvard community has made this article openly available.

Please share how this access benefits you. Submit a story.

\section{Accessibility}




\title{
Partisanship, Public Opinion, and Redistricting
}

\author{
Joshua Fougere, Stephen Ansolabehere, and Nathaniel Persily
}

\section{INTRODUCTION}

W Hen the Supreme Court first entered the political thicket with the "one person, one vote" cases of the 1960s, contemporaneous polls showed the Court to be on the right side of public opinion. In 1966, 76\% of Americans called the Supreme Court decision "rul[ing] all Congressional Districts had to have an equal number of people in them so each person's vote would count equally" "right" (Louis Harris and Associates Poll, The Roper Center for Public Opinion Research). ${ }^{1}$ Few, if any, innovations from the Warren Court years met with such deep approval by the public or have had comparable staying power. Indeed, majorities continue to support redistricting based on population equality (see Ansolabehere and Persily 2009). ${ }^{2}$

Beyond the easy-to-grasp concept of "one person, one vote," however, the public has little knowledge or opinion concerning the redistricting process. Polling on redistricting has been done sporadically and locally. ${ }^{3}$ As a consequence, only a few published articles attempt to describe or account for public attitudes concerning the complicated and low salience modern controversies surrounding redistricting on such issues as partisan or incumbent-protecting gerrymandering. ${ }^{4}$

This article analyzes survey data with the hope of gauging where Americans stand on various controversies surrounding the redistricting process. Part I briefly presents the public opinion surveys utilized and the questions most central to the analysis. Part II begins by examining the extent to which the public is uninformed and lacks opinions about redistricting. In short, Americans exhibit

Joshua Fougere is Associate, Sidley Austin LLP. Stephen Ansolabehere is Professor of Government, Harvard University. Nathaniel Persily is the Charles Keller Beekman Professor of Law and Political Science, Columbia Law School. both characteristics-must have neither heard much about the debate nor have opinions about it. Part III analyzes the structure of public opinion where it does exist. We begin by considering the impact of demographics on public opinion. Breaking up our discussion into subsections on fairness, satisfaction, and institutional actors, we then analyze variables related to partisanship and incum-

${ }^{1}$ And in $1969,52 \%$ of all respondents and $69 \%$ of those with an opinion favored "continuing with the present equal districting plan" (Gallup Poll, The Roper Center for Public Opinion Research).The 1966 survey conducted by Louis Harris \& Associates was based on personal interviews with a national adult sample of approximately 1,250. The 1969 survey conducted by Gallup Organization was based on personal interviews with a national adult sample of 1,551.

${ }^{2}$ The 2009 poll, designed by Ansolabehere and Persily, first asked "Do you think all legislative districts in your state should have the same number of people per district or is it okay for some to have more people than others?" $32 \%$ answered that districts should have equal populations, $53 \%$ stated that it is okay for district populations to differ somewhat, and only $12 \%$ thought that it is okay for some districts to have many more people than other districts. A substantial share of Americans, however, supports the "federal" model allowing for county representation in one house of a legislature. Fifty-four\% answered that it is better to have districts with equal populations in both chambers but $40 \%$ preferred one seat for each county in one chamber and equal population districts in the other chamber. ${ }^{3}$ In addition to the two surveys central to our study, some private polls have been conducted on redistricting. They are often state-specific and tied to a particular reform initiative (see, e.g., DiCamillo and Field 2008a, 2008b, 2005a, 2005b, 2005c; Tolbert, Smith, and Green 2009).

${ }^{4}$ We are aware of only a few such studies. Two brief papers on public attitudes toward redistricting both analyze the same dataset (see Pew Research Center 2006a; McDonald 2008; McDonald 2007). Another study using Pew data considers attitudes towards redistricting as they relate to general perceptions about politics, electoral winners and losers, and linedrawing authority (Bowler and Donovan 2009). A fourth focuses on unsuccessful initiatives in California and Ohio to analyze the effects of self-interested, strategic voting among so-called representational winners and losers (Tolbert, Smith, and Green 2009). 
bency protection. ${ }^{5} \mathrm{We}$ analyze, for instance, whether respondents feel differently about the process if their party controls their state's government than if they identify with the party out of power. We look at whether, in states with divided government, respondents are any more likely to view the results redistricting outcome as fair or satisfactory than in unified governments. And we distinguish between states with maps that are biased in one party's favor and those that are not. Overall, we find that respondents hold rational opinions. Winners are happier than losers, and voters generally desire a fair process achieved through methods muting the potential influence of partisanship in the line-drawing process. Part III concludes by briefly illustrating the strong relationship that opinions on redistricting have with opinions about politicians more generally.

\section{SURVEY METHODOLOGY AND DATA}

Our study focuses on two surveys conducted in 2006. The Pew Research Center, in association with the Brookings Institution and the Cato Institute, conducted a survey in October 2006 on "Electoral Competitiveness." $"$ The survey consisted of 2,006 adult respondents nationwide, with an oversample of respondents from districts with competitive U.S. House races in $2006 .^{7}$ Four of the questions asked bear directly on the redistricting issue. In addition to the Pew survey, we employ data from a poll conducted as part of the Cooperative Congressional Election Studies (CCES) designed by a team from MIT (2006). ${ }^{8}$ One thousand respondents were asked various questions related to the 2006 elections, four of which were about redistricting.

The questions in both studies track opinions on two general issues. First, several questions address basic opinion on and knowledge about drawing voting districts. Second, each survey contains a question about who is or should be responsible for drawing district lines. The precise wording of the CCES questions is as follows (2006a):

Every ten years states have to draw new Congressional and state legislative district boundaries.

Q30. Do you think districting in your state is done fairly?
Yes

No

Not Sure

No Opinion

Q31. Would you prefer that redistricting in your state was done by the state legislature or by an independent commission?

Legislature

Commission

Not Sure

No Opinion

Q32. Occasionally the courts have to settle disputes about redistricting. Do you think that courts in your state do a very good job in deciding questions about election districts, a good job, a poor job, or a very poor job?

The Pew Center asked the following questions (Pew Research Center 2006, 10):

Q50. As you may know, states with more than one seat in the U.S. House of Representatives redraw their congressional district boundaries from time to time. How much, if anything, have you heard or read about the debate over how these boundaries should be drawn - a lot, a little, or nothing at all?

Q51. Thinking specifically about [INSERT STATE], as far as you know, who is normally

\footnotetext{
${ }^{5}$ As discussed in more detail below, we observe a significant difference in overall responses to the questions about satisfaction and fairness in the surveys we rely on. The results do not necessarily contradict. A population may, for example, find the process to be unfair on average while nonetheless splitting on satisfaction and dissatisfaction. The disparity is, nonetheless, significant enough to warrant acknowledgment and even a question about the extent to which the polls are consistent.

${ }^{6}$ The data can be downloaded from < http://people-press.org/ dataarchive/ $>$.

${ }^{7}$ For this and additional details about the study methodology, see the study by the Pew Research Center (2006a and 2006b).

${ }^{8}$ For general information about the study, see $<$ http://web. mit.edu/polisci/portl/cces/commoncontent.html $>$ and the essay by Stephen Ansolabehere and Nathaniel Persily, Vote Fraud in the Eye of the Beholder: The Role of Public Opinion in the Challenge to Voter Identification Requirements (2008).
} 
in charge of how congressional district lines are drawn . . . is it . . ${ }^{9}$

Elected officials such as the state legislature A nonpartisan committee or panel

Don't know/Refused

Q52. Just your opinion, are you satisfied or dissatisfied with the way congressional district lines are drawn in your state, or don't you have an opinion about it?

Q53. What in particular are you dissatisfied about regarding the way [STATE]'s districts are drawn?

[Answer given]

Don't know/Refused

In addition to these studies, our discussion is supplemented with data from a Democracy Corps Poll in 2006, ${ }^{10} 2005$ and 2008 polls from the Field Research Corporation (DiCamillo and Field 2008a, 2008b, 2005a, 2005b, 2005c), and 2005 surveys from Ohio and California (see Tolbert, Smith, and Green 2009).

In each of the following sections, our dependent variables take two forms-ordered and binary. For ordered variables, we present coefficients from linear regressions to facilitate interpretation, but we have also performed ordered probits and multinomial logits. ${ }^{11}$ For binary variables, we use probit regressions. We also provide crosstabs of the data.

\section{THE LOW LEVEL OF KNOWLEDGE AND INFORMATION}

Any account of public opinion and redistricting must begin with a discussion of the low level of knowledge and information most respondents demonstrate when asked about the subject. ${ }^{12}$ We present here the data on the lack of information and knowledge from respondents about districting, and then look at the structure of non-opinion.

\section{Low information and knowledge}

The most direct evidence of low levels of information is from the Pew Center survey ${ }^{13}$ and the Field Research Corporation. Respondents in the
Pew Survey were explicitly asked how much they had heard about the debate over redrawing congressional district boundaries. Only $10 \%$ of all respondents and $12 \%$ of registered voters stated that they had heard "a lot." Among those same groups, $38 \%$ and $41 \%$, respectively, had heard "a little" about the issue. The largest number of respondents answered that they knew nothing about the debate$51 \%$ of all respondents and $47 \%$ of registered voters. Similarly, in the run-up to a 2005 ballot initiative on redistricting reform in California, Field asked voters how much they knew about redistricting. Just $11 \%$ answered "a great deal" and $27 \%$ said "some." By contrast, the majority of respondents had only seen, read, or heard "a little" (34\%) or "nothing at all" (28\%) (DiCamillo and Field, 2005c, 2).

Even when questions are not directly about awareness, responses reflect the low levels of knowledge people have about the subject. Table 1 presents the "not sure," "no opinion" and "don't know" responses for the other questions from Pew and CCES. The data add further support to the previous finding that only one-tenth of Americans reported knowing a lot about the debate. Indeed, in both surveys, the largest levels of uncertainty correspond to questions about the respondent's opinion on the issue-whether she is satisfied $(73 \%)$, whether she thinks the process is done fairly $(50 \%)$, and how well she thinks the courts do in settling disputes $(52 \%)$. With little or no knowledge about redistricting in general, we should expect to find few opinions on the substance of the matter.

Americans reveal a similar lack of knowledge about who is responsible for drawing districts. Forty-one percent are not sure or have no opinion on whether they would prefer redistricting to be done by the legislature or by an independent com-

\footnotetext{
${ }^{9}$ The study clarifies that "Montana, North Dakota, South Dakota, Vermont, and Wyoming each have only one Congressional district. Respondents from these states were not asked questions 51 through 53" (Pew Research Center 2006a, 10 n.2). ${ }^{10}$ The survey by Democracy Corps was conducted by Greenberg Quinlan Rosner Research based on telephone interviews with a national likely voters sample of 1,005 (The Roper Center for Public Opinion Research 2006).

${ }^{11}$ Results are on file with the authors. The significance of variables did not materially change.

${ }^{12}$ The results in this section track those in the literature finding that the public is poorly informed or pays little attention to process issues like redistricting (see, e.g., McDonald 2007, 14). ${ }^{13}$ McDonald reports the same low information results from the Pew study (McDonald 2008; McDonald 2007).
} 
TABle 1. UnCERTAinty By Question

\begin{tabular}{lcccr}
\hline & Not Sure & No Opinion & DK/Refuse & Total \\
\hline Pew Center & & & $47 \%$ & $47 \%$ \\
$\quad$ Who is in charge of drawing districts? & & $70 \%$ & $3 \%$ & $73 \%$ \\
$\quad$ Satisfied with the way districts are drawn? & & $14 \%$ & $50 \%$ \\
CCES & $36 \%$ & $14 \%$ & $41 \%$ \\
$\quad$ Districting done fairly? & $27 \%$ & & $52 \%$ \\
$\quad \begin{array}{l}\text { Prefer districting done by legislature of } \\
\quad \text { independent commission? }\end{array}$ & $52 \%$ & & \\
How well do courts do in districting cases?
\end{tabular}

For the precise wording, see Part I, "Survey Methodology and Data." Data are weighted. The question from the Pew Survey that asks those who said they were dissatisfied with the process what in particular they were dissatisfied about is not reported for the obvious reason that it is only asked to a subset of respondents who had already reported having an opinion. Fourteen percent of those 294 individuals did not know or refused to answer.

mission. Likewise, when asked not about their opinion but the factual question-"Who is in charge of drawing congressional districts in your state?"forty-seven percent did not know. In addition to the high percentage who answered "Don't know" to this question, quite a few of those who did answer had incorrect information. Specifically, twenty-one percent of the respondents who answered the question were wrong about who actually drew the congressional districts in their state. ${ }^{14}$ These misinformed individuals comprised eleven percent of all respondents, therefore yielding a total of at least fifty-eight percent of Americans who do not know what body is responsible for redistricting. ${ }^{15}$

\section{Structure of non-opinion: Breaking down the likelihood of having an opinion}

With these general trends as the backdrop, we proceed to analyze low information and knowledge, first considering demographic characteristics and then asking if other factors help to explain where Americans do and do not have opinions on redistricting. Table 2 presents the responses to Pew's direct question about awareness, and Table 3 gives figures for the remaining questions by variable.

Demographics and other individual characteristics. We begin by considering three immutable demographic characteristics: race, gender, and age. With respect to race, there is considerable consistency among African Americans, Hispanics, and whites on most questions, including Pew's direct question about knowledge, and no one group is always most or least informed. On questions about the fairness of redistricting or satisfaction, racial groups do not differ much, with single-digit percentage points separating the most and least likely to express an opinion. When asked about who draws the districts, whites were less likely to respond to the factual question, and Hispanics had an opinion about who should draw districts more often than whites or African Americans. Regression analyses support these findings of non-differentiation: race is never a significant predictor of the likelihood a respondent has an opinion or is knowledgeable about redistricting (see Appendix A).

With respect to age and gender, there appears to be some distinction based on the surveys. In both, women are significantly more likely than men to be unsure or to have no opinion, sometimes by twice as much. ${ }^{16}$ This effect is more pronounced in the CCES survey than in the Pew study. That said, the

\footnotetext{
14 The correct authority for congressional districts was matched up with a table of weighted responses to Question 51 from the Pew Study by state. The percentages of Correct and Incorrect answers were then calculated.

${ }^{15}$ We say "at least" because presumably an unknown number of respondents were guessing. Those who guessed incorrectly are included in the $58 \%$ while those who guessed correctly, despite not knowing who draws the lines, are not captured in that figure.

16 This result tracks a well-known phenomenon that women are more likely to say "not sure" or "don't know" than men, even when they have an opinion.
} 
Table 2. Pew Center Question 50 By Demographics

\begin{tabular}{|c|c|c|c|c|}
\hline & \multicolumn{4}{|c|}{$\begin{array}{c}\text { How much, if anything, have you heard or read about the debate } \\
\text { over how congressional districts are drawn? }\end{array}$} \\
\hline & A lot & A little & Nothing & Don't Know \\
\hline \multicolumn{5}{|l|}{ Race } \\
\hline Black & $9 \%$ & $46 \%$ & $45 \%$ & $1 \%$ \\
\hline Hispanic & $8 \%$ & $40 \%$ & $49 \%$ & $3 \%$ \\
\hline White & $10 \%$ & $38 \%$ & $52 \%$ & $1 \%$ \\
\hline \multicolumn{5}{|l|}{ Gender } \\
\hline Men & $13 \%$ & $39 \%$ & $48 \%$ & $1 \%$ \\
\hline Women & $7 \%$ & $38 \%$ & $54 \%$ & $1 \%$ \\
\hline \multicolumn{5}{|l|}{ Age } \\
\hline 18 to 29 & $4 \%$ & $31 \%$ & $64 \%$ & $1 \%$ \\
\hline 30 to 49 & $10 \%$ & $36 \%$ & $53 \%$ & $1 \%$ \\
\hline 50 plus & $13 \%$ & $43 \%$ & $43 \%$ & $2 \%$ \\
\hline \multicolumn{5}{|l|}{ Education } \\
\hline No HS & $4 \%$ & $38 \%$ & $54 \%$ & $4 \%$ \\
\hline HS Diploma & $6 \%$ & $38 \%$ & $55 \%$ & $2 \%$ \\
\hline Post-HS Study & $9 \%$ & $38 \%$ & $53 \%$ & $0 \%$ \\
\hline 4 Yr College & $12 \%$ & $38 \%$ & $50 \%$ & $0 \%$ \\
\hline Post-Grad & $26 \%$ & $42 \%$ & $32 \%$ & $0 \%$ \\
\hline \multicolumn{5}{|l|}{ Partisanship } \\
\hline Republican & $9 \%$ & $39 \%$ & $51 \%$ & $0 \%$ \\
\hline Democrat & $10 \%$ & $46 \%$ & $43 \%$ & $1 \%$ \\
\hline Independent & $10 \%$ & $32 \%$ & $57 \%$ & $1 \%$ \\
\hline In Party & $10 \%$ & $44 \%$ & $44 \%$ & $2 \%$ \\
\hline Out Party & $14 \%$ & $40 \%$ & $46 \%$ & $1 \%$ \\
\hline \multicolumn{5}{|l|}{ News attention } \\
\hline Very closely & $24 \%$ & $46 \%$ & $30 \%$ & $0 \%$ \\
\hline Fairly closely & $8 \%$ & $42 \%$ & $49 \%$ & $1 \%$ \\
\hline Not too closely & $7 \%$ & $34 \%$ & $58 \%$ & $1 \%$ \\
\hline Not at all close & $3 \%$ & $31 \%$ & $66 \%$ & $0 \%$ \\
\hline \multicolumn{5}{|l|}{ Geography } \\
\hline Recent Issue St & $14 \%$ & $40 \%$ & $46 \%$ & $1 \%$ \\
\hline Other States & $7 \%$ & $37 \%$ & $54 \%$ & $1 \%$ \\
\hline
\end{tabular}

Data are weighted. Note further that the Pew study follows the census categories for race. Accordingly, for Pew questions here and in subsequent tables, Hispanic includes Hispanic Whites, while White includes only Non-Hispanic Whites.

regressions in Appendix A show that gender is a significant predictor of non-opinion for all questions. Age cohorts track a consistent pattern in the Pew survey - younger respondents are less knowledgeable than older ones in each question. In the CCES questions, on the other hand, there is little evidence of any pattern. In line with this, age behaves differently in the regressions based on the survey. It is statistically significant in regressions for almost all Pew questions but never so for CCES.

Education generally yields predictable results. On Pew's question about how much respondents knew of the redistricting debate, for example, an increase in education level corresponds with a greater number of respondents who know "a lot." Similarly, higher education attainment is associated with fewer "not sure" or "no opinion" responses on all other questions. Likewise, it is significant in several regressions presented in Appendix A.

The impact of partisanship, like age, differs between the two studies. In the Pew study, Democrats were consistently the most informed respondents about redistricting as compared to Republicans and Independents. "Only" forty-three percent of Democrats reported having heard nothing about the issue, compared to fifty-one and fifty-seven percent in the other two groups, respectively. In line with that response, Democrats had the highest response rate to questions about satisfaction and redistricting authority. By contrast, Democrats were consistently the least knowledgeable and expressed the fewest 
Table 3. Demographics of No Opinion Total of "No Opinion," "Not Sure," AND "DON'T KNOW/REFusE"

\begin{tabular}{|c|c|c|c|c|c|}
\hline & \multicolumn{3}{|c|}{ Opinion about the process } & \multicolumn{2}{|c|}{ Who draws districts } \\
\hline & CCES 30 & CCES 32 & Pew 52 & CCES 31 & Pew 51 \\
\hline \multicolumn{6}{|l|}{ Race } \\
\hline Black & $54 \%$ & $48 \%$ & $72 \%$ & $46 \%$ & $37 \%$ \\
\hline Hispanic & $46 \%$ & $48 \%$ & $78 \%$ & $35 \%$ & $40 \%$ \\
\hline White & $50 \%$ & $55 \%$ & $73 \%$ & $42 \%$ & $50 \%$ \\
\hline \multicolumn{6}{|l|}{ Gender } \\
\hline Men & $38 \%$ & $41 \%$ & $68 \%$ & $28 \%$ & $41 \%$ \\
\hline Women & $61 \%$ & $63 \%$ & $77 \%$ & $54 \%$ & $53 \%$ \\
\hline \multicolumn{6}{|l|}{ Age } \\
\hline 18 to 29 & $43 \%$ & $56 \%$ & $83 \%$ & $35 \%$ & $56 \%$ \\
\hline 30 to 49 & $49 \%$ & $51 \%$ & $76 \%$ & $45 \%$ & $48 \%$ \\
\hline 50 plus & $51 \%$ & $52 \%$ & $65 \%$ & $39 \%$ & $42 \%$ \\
\hline \multicolumn{6}{|l|}{ Education } \\
\hline No HS & $79 \%$ & $67 \%$ & $78 \%$ & $55 \%$ & $52 \%$ \\
\hline HS Diploma & $62 \%$ & $61 \%$ & $76 \%$ & $56 \%$ & $51 \%$ \\
\hline Post-HS Study & $46 \%$ & $48 \%$ & $71 \%$ & $36 \%$ & $47 \%$ \\
\hline 4 Yr College & $39 \%$ & $48 \%$ & $73 \%$ & $38 \%$ & $42 \%$ \\
\hline Post-Grad & $38 \%$ & $42 \%$ & $60 \%$ & $18 \%$ & $37 \%$ \\
\hline \multicolumn{6}{|l|}{ Partisanship } \\
\hline Republican & $47 \%$ & $50 \%$ & $72 \%$ & $43 \%$ & $50 \%$ \\
\hline Democrat & $56 \%$ & $60 \%$ & $69 \%$ & $46 \%$ & $40 \%$ \\
\hline Independent & $47 \%$ & $50 \%$ & $76 \%$ & $36 \%$ & $48 \%$ \\
\hline In Party & $49 \%$ & $50 \%$ & $71 \%$ & $46 \%$ & $48 \%$ \\
\hline Out Party & $51 \%$ & $51 \%$ & $72 \%$ & $41 \%$ & $42 \%$ \\
\hline \multicolumn{6}{|l|}{ News attention } \\
\hline Very closely & & & $53 \%$ & & $30 \%$ \\
\hline Fairly closely & & & $71 \%$ & & $41 \%$ \\
\hline Not too closely & & & $82 \%$ & & $56 \%$ \\
\hline Not at all close & & & $85 \%$ & & $57 \%$ \\
\hline \multicolumn{6}{|l|}{ Geography } \\
\hline Recent Issue St & $46 \%$ & $54 \%$ & $74 \%$ & $40 \%$ & $42 \%$ \\
\hline Other States & $53 \%$ & $46 \%$ & $73 \%$ & $43 \%$ & $49 \%$ \\
\hline
\end{tabular}

Data are weighted. The question wording is as follows: CCES 30 ("Do you think districting in your state is done fairly?"), CCES 32 ("Occasionally the courts have to settle disputes about redistricting. Do you think that courts in your state do a very good job in deciding questions about election districts, a good job, a poor job, or a very poor job?"); Pew 52 ("Just your opinion, are you satisfied or dissatisfied with the way congressional district lines are drawn in your state, or don't you have an opinion about it?"), CCES 31 ("Would you prefer that redistricting in your state was done by the state legislature or by an independent commission?"), and Pew 51 ("Thinking specifically about [INSERT STATE], as far as you know, who is normally in charge of how congressional district lines are drawn . . . is it elected officials such as the state legislature or a nonpartisan committee or panel?") (see CCES 2006; Pew Research Center 2006a).

opinions in the CCES survey. They had the highest rate of "not sure," "no opinion," or "don't know" responses among the three groups on all questions. And for two questions - about fairness and satisfaction with the courts - about ten percent more Republicans than Democrats gave substantive answers or opinions.

Partisanship, however, was generally not significant in the regressions presented in Appendix A after controlling for other demographic variables. ${ }^{17} \mathrm{In}$ Pew's direct question about awareness, being a Democrat was a significant predictor of a greater likelihood to have heard more about the debate. The only other question for which partisanship was statistically significant was the Pew survey question concerning who draws the lines in the respondent's state. Again, Democrats were more likely to give an

${ }^{17}$ All regressions were also run using a continuous variable for party identification instead of binary variables for Republican and Democrat, as reported in the appendices. Because differences were very slight and did not materially change our results, we use party dummies to facilitate our discussion and comparisons with the tables. 
answer. All other political orientation variables ${ }^{18}$ were insignificant.

Finally, we note an entirely unsurprising result from the Pew data. ${ }^{19}$ That is, respondents reporting that they follow news about candidates and elections more closely in their state or district were also more likely to have heard more about the redistricting debate, more likely to have an opinion about how lines should be drawn, and more likely to know who is in charge of drawing district lines in their state. This variable is strongly significant in all of the regressions presented in Appendix A.

State-based explanations? Here we look at an additional variable for its effect on the likelihood that Americans have an opinion or are knowledgeable about redistricting. Specifically, we consider geography, ${ }^{20}$ separating out respondents from states in which redistricting has been more "in the news." ${ }^{21}$ We define that category to include states where redistricting has been subject to an initiative since $2000^{22}$ and states in which there was substantial and controversial litigation this decade. ${ }^{23}$ Our list of such states is: Arizona, California, Colorado, Georgia, Michigan, Ohio, Pennsylvania, and Texas. ${ }^{24}$

As with many other predictors, we find somewhat mixed results in the Pew and CCES data. In response to Pew's question about awareness of the redistricting debate, respondents in these states are considerably more aware. Table 2 shows higher percentages of those knowing "a lot" and "a little" as opposed to "nothing," and this variable is strongly significant in the regressions presented in Table A1, even after controlling for demographics and partisanship. ${ }^{25}$ By contrast, the variable is insignificant in almost all other regressions displayed in Tables $\mathrm{A} 2$ and $\mathrm{A} 3$. While Table 3 illustrates some interesting results - a higher rate of opinions on fairness of the process but not on the performance of courts, for instance-any such associations are not statistically significant in our regressions.

Exposure has a limited effect on awareness of the redistricting authority. When Pew asked respondents which authority draws the lines in their states, $82 \%$ of those who answered the question identified the correct authority in states with more recent redistricting action, whereas $77 \%$ were correct in other states. Moreover, people in states with a recent redistricting initiative or litigation responded that they knew who was in charge of re- districting at a higher rate than did people in other states, and this result was significant in the regression (see Table A3). ${ }^{26}$

Surveys conducted prior to the initiatives in California and Ohio track these results with added detail. ${ }^{27} \mathrm{We}$ see, for example, that poll timing matters as voter awareness starts off low even in these states but grows, as one would expect, closer to election day. In California's 2005 election, only four in ten

${ }^{18}$ In addition to dummies for Republicans and for ideology, we include dummies for whether the respondent was a member of the party in control in her state (the "in party") or a member of the party out of control (the "out party"), if her state's legislature and governorship were all of the same party. It is not entirely obvious why this would predict likelihood to have an opinion, but it was included on the possible theory that a respondent may be more or less motivated to stay informed of the issue if his party was in or out of power. Nonetheless, as Appendix A reveals, the variables were not significant.

${ }^{19} \mathrm{We}$ did not find the same variable in the CCES study.

${ }^{20}$ Census region was also included in our regressions but was not significant.

${ }^{21}$ McDonald performed a similar analysis just on the Pew study data and just for three states: California, Ohio, and Texas (2008, 156-57).

${ }^{22}$ For a list of redistricting initiatives, see Stephanopoulas (2007).

${ }^{23}$ For a list of redistricting cases by state in the 2000 s, see $<$ http://www.senate.leg.state.mn.us/departments/scr/redist/red sum2000/redsum2000.htm >.

${ }^{24}$ We also split up states with litigation and those with initiatives but the pattern did not change. In analyses where the variable was significant grouping the two together, both remained significant when separated. Similarly, where the grouped variable was not significant, splitting up litigation and initiative states did not result in either becoming significant on its own. ${ }^{25}$ McDonald also reports that voters "learn" when exposed to the issue, and thus our findings track his on this metric, despite considering more states (see McDonald 2007, 14).

${ }^{26}$ Although not reported in Appendix A, we also ran probit regressions testing whether another geographic variable was a significant predictor of respondents' likelihood to know who was responsible for district lines. Specifically, we used dummies for states where the final lines were drawn by a commission, partisan commission, or courts (Ansolabehere, Fougere, and Persily 2010). We did not find significance, indicating that knowledge does not shift based on the different authorities for drawing lines in a given state. Moreover, running the same regressions against a dependent variable equal to 1 if the respondent states that she "knows" a commission drew the lines in her state (based on Pew question 51) further highlight the low levels of awareness. There, the flag for partisan commission states was significant but negative. Thus, people in those states were less likely to report knowing that a commission drew their lines.

${ }^{27}$ In 2005, California's Proposition 77 proposed turning redistricting authority over to a panel of retired judges. Ohio similarly proposed that an independent commission draw its lines. In 2008, California's Proposition 11 proposed shifting redistricting authority to a non-partisan, 14-member commission. 
voters had heard of redistricting in February (DiCamillo and Field, 2005c, 2). By June, 50\% of registered voters and $60 \%$ of likely voters were aware of Proposition 77 (DiCamillo and Field, 2005 b). On the eve of the election, about $10 \%$ more voters knew about the proposal (see Tolbert, Smith, and Green 2009, n.10). Similarly, in Ohio in 2005, only one-third of respondents had not heard of or did not have an opinion on the reform measure shortly before the election (id., 98). The low level of information and opinions nonetheless remains high relative to other topics. A few months before California's second reform attempt in 2008, for instance, only $23 \%$ of respondents had heard of Proposition 11, whereas $45 \%$ had heard of a measure concerning abortion (DiCamillo and Field, 2008b).

\section{STRUCTURE OF OPINION: SATISFACTION AND CONCERNS IN DRAWING DISTRICTS}

We turn to the structure of public opinion among individuals who gave substantive responses. We begin by considering how demographic variables help to explain beliefs about redistricting. Finding mixed results, we then move to the crux of our findings, discussing how partisanship, incumbency, and institutional responsibilities affect voters' perceptions. Finally, we observe that a distaste for politicians generally correlates with opinions about redistricting.

\section{Demographics and individual characteristics}

Tables 4A and 4B present the breakdown of opinions by demographics and political party. Table 4A gives percent positive and negative responses from all respondents and 4B displays opinions only among those with responsive answers.

As before, we begin by considering race. Overall opinion on the redistricting process again differs between the two surveys. When CCES asked whether respondents thought districting is done fairly, whites were twice as likely as African Americans and Hispanics to answer yes. Likewise, though not as starkly, a higher percentage of minorities than whites stated that the process was not fair. In the Pew study, by contrast, only small differences existed between racial groups as to their satisfaction with the way congressional districts are drawn. Race was never statistically significant in our regressions

Table 4A. Demographics of Opinion (All Respondents)

\begin{tabular}{|c|c|c|c|c|c|c|c|c|}
\hline & \multicolumn{2}{|c|}{$\begin{array}{c}\text { Think districting } \\
\text { done fairly }\end{array}$} & \multicolumn{2}{|c|}{$\begin{array}{l}\text { Satisfied with } \\
\text { the way } \\
\text { lines drawn }\end{array}$} & \multicolumn{2}{|c|}{$\begin{array}{l}\text { Courts do a_job } \\
\text { settling disputes }\end{array}$} & \multicolumn{2}{|c|}{$\begin{array}{c}\text { Prefer an independent } \\
\text { commission or } \\
\text { legislature }\end{array}$} \\
\hline & Yes & No & Yes & No & Good/V good & Poor/V poor & Comm. & Leg. \\
\hline \multicolumn{9}{|l|}{ Race } \\
\hline Black & $11 \%$ & $36 \%$ & $11 \%$ & $17 \%$ & $30 \%$ & $22 \%$ & $46 \%$ & $8 \%$ \\
\hline Hispanic & $11 \%$ & $42 \%$ & $11 \%$ & $11 \%$ & $30 \%$ & $22 \%$ & $52 \%$ & $13 \%$ \\
\hline White & $21 \%$ & $29 \%$ & $13 \%$ & $14 \%$ & $19 \%$ & $26 \%$ & $49 \%$ & $10 \%$ \\
\hline \multicolumn{9}{|l|}{ Gender } \\
\hline Men & $21 \%$ & $41 \%$ & $17 \%$ & $16 \%$ & $24 \%$ & $35 \%$ & $58 \%$ & $14 \%$ \\
\hline Women & $17 \%$ & $22 \%$ & $10 \%$ & $13 \%$ & $18 \%$ & $18 \%$ & $40 \%$ & $6 \%$ \\
\hline \multicolumn{9}{|l|}{ Age } \\
\hline 18 to 29 & $26 \%$ & $31 \%$ & $8 \%$ & $9 \%$ & $26 \%$ & $18 \%$ & $52 \%$ & $13 \%$ \\
\hline 30 to 49 & $21 \%$ & $30 \%$ & $11 \%$ & $13 \%$ & $23 \%$ & $26 \%$ & $46 \%$ & $9 \%$ \\
\hline 50 plus & $16 \%$ & $33 \%$ & $17 \%$ & $18 \%$ & $19 \%$ & $30 \%$ & $51 \%$ & $10 \%$ \\
\hline \multicolumn{9}{|l|}{ Education } \\
\hline No HS & $17 \%$ & $4 \%$ & $8 \%$ & $14 \%$ & $9 \%$ & $25 \%$ & $32 \%$ & $13 \%$ \\
\hline HS Diploma & $18 \%$ & $20 \%$ & $11 \%$ & $13 \%$ & $17 \%$ & $22 \%$ & $36 \%$ & $8 \%$ \\
\hline Post-HS Study & $22 \%$ & $34 \%$ & $12 \%$ & $16 \%$ & $26 \%$ & $26 \%$ & $51 \%$ & $12 \%$ \\
\hline 4 Yr College & $20 \%$ & $49 \%$ & $18 \%$ & $11 \%$ & $24 \%$ & $33 \%$ & $67 \%$ & $9 \%$ \\
\hline Post-Grad & $14 \%$ & $48 \%$ & $19 \%$ & $21 \%$ & $24 \%$ & $34 \%$ & $72 \%$ & $10 \%$ \\
\hline \multicolumn{9}{|l|}{ Partisanship } \\
\hline Republican & $31 \%$ & $23 \%$ & $17 \%$ & $11 \%$ & $23 \%$ & $27 \%$ & $42 \%$ & $15 \%$ \\
\hline Democrat & $14 \%$ & $29 \%$ & $13 \%$ & $18 \%$ & $19 \%$ & $21 \%$ & $45 \%$ & $9 \%$ \\
\hline Independent & $13 \%$ & $39 \%$ & $10 \%$ & $14 \%$ & $21 \%$ & $29 \%$ & $56 \%$ & $7 \%$ \\
\hline
\end{tabular}

Questions, respectively, are: CCES 30, Pew 52, CCES 32, and CCES 31. Data are weighted. 
Table 4B. Demographics of Opinion (Respondents With Opinions)

\begin{tabular}{|c|c|c|c|c|}
\hline & $\begin{array}{c}\text { Think districting } \\
\text { done fairly }\end{array}$ & $\begin{array}{l}\text { Satisfied with the } \\
\text { way lines drawn }\end{array}$ & $\begin{array}{l}\text { Courts do good/v } \\
\text { good job } \\
\text { settling disputes }\end{array}$ & $\begin{array}{l}\text { Prefer an } \\
\text { independent } \\
\text { commission }\end{array}$ \\
\hline \multicolumn{5}{|l|}{ Race } \\
\hline Black & $23 \%$ & $41 \%$ & $57 \%$ & $86 \%$ \\
\hline Hispanic & $21 \%$ & $50 \%$ & $58 \%$ & $81 \%$ \\
\hline White & $42 \%$ & $47 \%$ & $43 \%$ & $83 \%$ \\
\hline \multicolumn{5}{|l|}{ Gender } \\
\hline Men & $34 \%$ & $52 \%$ & $41 \%$ & $80 \%$ \\
\hline Women & $44 \%$ & $42 \%$ & $50 \%$ & $87 \%$ \\
\hline \multicolumn{5}{|l|}{ Age } \\
\hline 18 to 29 & $46 \%$ & $46 \%$ & $59 \%$ & $80 \%$ \\
\hline 30 to 49 & $41 \%$ & $46 \%$ & $47 \%$ & $84 \%$ \\
\hline 50 plus & $32 \%$ & $48 \%$ & $39 \%$ & $83 \%$ \\
\hline \multicolumn{5}{|l|}{ Education } \\
\hline No HS & $80 \%$ & $36 \%$ & $26 \%$ & $72 \%$ \\
\hline HS Diploma & $47 \%$ & $46 \%$ & $43 \%$ & $81 \%$ \\
\hline Post-HS Study & $42 \%$ & $43 \%$ & $50 \%$ & $81 \%$ \\
\hline 4 Yr College & $32 \%$ & $62 \%$ & $43 \%$ & $88 \%$ \\
\hline Post-Grad & $23 \%$ & $48 \%$ & $42 \%$ & $88 \%$ \\
\hline \multicolumn{5}{|l|}{ Partisanship } \\
\hline Republican & $57 \%$ & $62 \%$ & $46 \%$ & $73 \%$ \\
\hline Democrat & $33 \%$ & $42 \%$ & $48 \%$ & $83 \%$ \\
\hline Independent & $26 \%$ & $41 \%$ & $43 \%$ & $89 \%$ \\
\hline
\end{tabular}

Questions, respectively, are: CCES 30, Pew 52, CCES 32, and CCES 31. Data are weighted.

on trichotomous ordered variables (see Appendix B) ${ }^{28}$ for fairness or for satisfaction when controlling for other demographic characteristics (see Tables B1 and B3).

On specific aspects of the process, no consistent patterns emerged between racial groups. Although African Americans display slightly more distaste for legislatures drawing the lines, preferences on the best line-drawing authority are largely the same across races. Our regressions support this finding, showing no significance for racial variables in Tables B2 and B4. However, there is greater variation in opinion on the courts' involvement in dispute settlement. Blacks and Hispanics were eight percentage points more likely to think the courts do a good or very good job than a poor or very poor job-30\% to $22 \%$ of all respondents. Whites, on the other hand, exhibit greater distrust for the courts. Twenty-six percent of all respondents believe that they do a poor or very poor job, compared to 19 percent who answered good or very good. Again, our regressions back up these results, finding some significance in race variables when testing respondents' opinions on the courts' work in redistricting disputes (see Appendix B). ${ }^{29}$

As to remaining demographic characteristicsage, gender, and education - the data show some variation but not much. Because of the overwhelming percentage of females who did not express an opinion, their response percentages are lower across the board. As such, any gender differences are difficult to perceive. Age categories reveal some distinctions. Among CCES respondents, older respondents are less likely to find the process fair. Again, however, Pew's question about satisfaction yields more opinions with age, but an equal split in satisfaction and dissatisfaction at all ages. Older respondents are more likely to express negative views of courts' handling of redistricting disputes increase with age, but opinions on line-drawing authority do not vary much. Finally, with respect to education, more educated CCES respondents find redistricting to be unfair, while among Pew respondents, satisfaction levels are

\footnotetext{
${ }^{28}$ Responses were ordered as follows: yes/satisfied, not sure/don't know/no opinion, no/dissatisfied.

${ }^{29}$ Specifically, both Hispanic and White are significant in Table B2, while Hispanic is significant in Table B4. In Table B2, White has a positive sign, indicating an increase in appreciation for the courts for white respondents. Though this sounds odd in light of Table 4A, the magnitude of the white coefficient is smaller than that for Black or Hispanic. As such, whites are less likely than minorities to support the courts, which accords with the description above.
} 
mostly even at all levels. Higher education attainment is also associated with a greater preference for independent commissions drawing district lines.

Regressions displayed in Appendix B support these findings. Gender is generally insignificant. As the tables suggest, age is significant and negative in regressions testing views on fairness and the courts, but is insignificant with respect to satisfaction and linedrawing authority. And lastly, more educated respondents are more likely to view the process as unfair and more likely to prefer Commissions.

Partisanship is associated with divided opinion along all metrics about redistricting. In general, more Republicans are more likely to think the process is done fairly and to be satisfied with the way in which district lines are drawn. For non-Republicans, the opposite pattern holds. Twice as many Democrats and Independents believe that redistricting is not done fairly as think it is fair. ${ }^{30}$ Democrats and Independents are also somewhat less satisfied with the way lines are drawn, in contrast to Republicans who are somewhat more satisfied. Moreover, slightly more Democrats and Independents prefer that lines be drawn by an independent commission than do Republicans, and Republicans prefer a legislative body about twice as often as Dem-ocrats and Independents. ${ }^{31}$

\section{Partisanship and incumbency}

We now turn to the heart of our analysis concerning the influences of partisanship and incumbency protection on the redistricting process. The redistricting process is carried out by legislatures in most states (National Conference of State Legislatures 2009, 178-179). Criticism of the process reflects concerns about partisan or self-interested gerrymandering of districts. We attempt in this section to gauge the pervasiveness of this concern among the general public.

At the outset, we make a few observations. First, the strong lack of opinion described in Part II, "The Low Level of Knowledge and Information," implies that what we observe in substantive opinions here is leveraged off the very few respondents who actually have opinions about redistricting. Second, although we consider several variables separately, many are closely related. Whether a state has a divided government, for instance, is highly correlated with whether its redistricting plan is biased in favor of one party. Whether a state's plan is biased is also closely tied to whether partisan or non-partisan in- stitutions were responsible for drawing district lines (see note 42 ). Not only should such variables be interpreted together, but many variables for which we observe differences in the tables do not show up as significant in our regressions because their effect is likely being captured by other variables.

Finally, although closely related, we consider opinions on fairness, satisfaction and institutional responsibility separately below. This facilitates the discussion and accounts for the fact that our questions come from two different surveys. The CCES survey, for example, asks just about redistricting while Pew explicitly refers to U.S. congressional districts. To the extent that some variables described below are more applicable to state district lines, this might explain some differences between the surveys. ${ }^{32}$ Furthermore, fairness and satisfaction are distinct: a voter might be "satisfied" with a redistricting outcome while nonetheless finding the process unfair. For all that, however, the issues certainly parallel one another in many respects, and that should be clear in our discussion and results.

On the whole, we find that people's opinions are not irrational. Success at the polls affects opinions. Moreover, voters appear to desire fairness which, along with satisfaction, is best achieved by dividing parties and institutions to mitigate self-interest in the redistricting process. ${ }^{33}$

\footnotetext{
${ }^{30}$ Californians are no different. In February 2005, more California Democrats felt that the process was unfair than did Republicans. Majorities of all party identifiers considered the process unfair. Question wording may explain why, as the question appears biased towards negative responses. The poll asked "do you feel that the way the state's district lines were redrawn after the last census was generally fair and balanced, or were they redrawn to give the incumbent party an unfair advantage when running for election in each district?" (DiCamillo and Field 2005c).

${ }^{31}$ The partisanship variables - that is, party, ideology, and in and out party membership-do not achieve statistical significance in the regressions reported in Appendix B.

${ }^{32}$ Of course, it is also quite possible, given their general lack of information, that voters do not perceive any differences between state legislative and congressional redistricting.

${ }^{33}$ Another survey, which is not considered in detail due to its strong bias in question wording, reveals a similar distaste for drawing districts that result in strong partisanship. A January 2006 Democracy Corps Poll asked how a proposal to "require that Congressional districts be drawn to encourage competitive elections to reduce the number of extreme partisans in Congress" would affect their likelihood to support the candidate. A strong majority (68\%) stated that their support would increase, with $28 \%$ answering "much more likely," $29 \%$ "somewhat more likely" and 11\% "a little more likely" (Democracy Corps Poll, The Roper Center for Public Opinion Research 2006).
} 
Table 5A. Geography-Based Opinion (All Respondents)

\begin{tabular}{|c|c|c|c|c|c|c|c|c|}
\hline & \multicolumn{2}{|c|}{$\begin{array}{l}\text { Think districting } \\
\text { done fairly }\end{array}$} & \multicolumn{2}{|c|}{$\begin{array}{l}\text { Satisfied with } \\
\text { the way } \\
\text { lines drawn }\end{array}$} & \multicolumn{2}{|c|}{$\begin{array}{l}\text { Courts do a jo job } \\
\text { settling disputes }\end{array}$} & \multicolumn{2}{|c|}{$\begin{array}{c}\text { Prefer an independent } \\
\text { commission or } \\
\text { legislature }\end{array}$} \\
\hline & Yes & No & Yes & $\mathrm{No}$ & Good/V good & Poor $/ V$ poor & Comm. & Leg. \\
\hline \multicolumn{9}{|l|}{ Recent Controversy } \\
\hline Yes & $14 \%$ & $41 \%$ & $12 \%$ & $15 \%$ & $19 \%$ & $33 \%$ & $51 \%$ & $11 \%$ \\
\hline No & $22 \%$ & $26 \%$ & $14 \%$ & $14 \%$ & $22 \%$ & $23 \%$ & $48 \%$ & $10 \%$ \\
\hline \multicolumn{9}{|l|}{ Partisanship } \\
\hline In Party & $34 \%$ & $18 \%$ & $15 \%$ & $15 \%$ & $25 \%$ & $24 \%$ & $34 \%$ & $21 \%$ \\
\hline Out Party & $16 \%$ & $34 \%$ & $10 \%$ & $18 \%$ & $20 \%$ & $30 \%$ & $49 \%$ & $10 \%$ \\
\hline \multicolumn{9}{|l|}{ State Control } \\
\hline Republican & $25 \%$ & $24 \%$ & $9 \%$ & $16 \%$ & $24 \%$ & $25 \%$ & $47 \%$ & $12 \%$ \\
\hline Democrat & $12 \%$ & $40 \%$ & $11 \%$ & $16 \%$ & $19 \%$ & $33 \%$ & $47 \%$ & $11 \%$ \\
\hline Split & $19 \%$ & $32 \%$ & $16 \%$ & $13 \%$ & $22 \%$ & $25 \%$ & $51 \%$ & $9 \%$ \\
\hline \multicolumn{9}{|l|}{ State Bias } \\
\hline States with bias & $13 \%$ & $36 \%$ & $10 \%$ & $16 \%$ & $18 \%$ & $31 \%$ & $53 \%$ & $10 \%$ \\
\hline States without bias & $20 \%$ & $32 \%$ & $14 \%$ & $13 \%$ & $22 \%$ & $25 \%$ & $50 \%$ & $10 \%$ \\
\hline \multicolumn{9}{|l|}{ Final Line Drawer } \\
\hline Legislature & $13 \%$ & $38 \%$ & $10 \%$ & $16 \%$ & $18 \%$ & $30 \%$ & $50 \%$ & $11 \%$ \\
\hline Partisan Comm. & $16 \%$ & $37 \%$ & $14 \%$ & $14 \%$ & $20 \%$ & $34 \%$ & $53 \%$ & $12 \%$ \\
\hline Commission & $22 \%$ & $26 \%$ & $12 \%$ & $14 \%$ & $25 \%$ & $19 \%$ & $55 \%$ & $6 \%$ \\
\hline Courts & $24 \%$ & $25 \%$ & $13 \%$ & $12 \%$ & $25 \%$ & $24 \%$ & $45 \%$ & $7 \%$ \\
\hline
\end{tabular}

Questions, respectively, are: CCES 30, Pew 52, CCES 32, and CCES 31. Data are weighted.

For the variables discussed in the following three subsections, Tables 5A and 5B present percentages for all respondents and among those with an opinion.

Fairness. We begin with fairness. Overall, when asked by CCES if they thought redistricting was done fairly, thirty-one percent of all respondents and sixty-two percent of those giving an answer said "No." Only nineteen percent of all Americans and thirty-eight percent of those with an opinion thought it was carried out fairly in their state. Moreover, respondents in states in which there was a recent re-

Table 5B. Geography-Based Opinion (Respondents With Opinions)

\begin{tabular}{|c|c|c|c|c|}
\hline & $\begin{array}{l}\text { Think districting } \\
\text { done fairly }\end{array}$ & $\begin{array}{l}\text { Satisfied with the } \\
\text { way lines drawn }\end{array}$ & $\begin{array}{l}\text { Courts do good/v } \\
\text { good job } \\
\text { settling disputes }\end{array}$ & $\begin{array}{l}\text { Prefer an } \\
\text { independent } \\
\text { commission }\end{array}$ \\
\hline \multicolumn{5}{|l|}{ Recent Controversy } \\
\hline Yes & $26 \%$ & $44 \%$ & $37 \%$ & $82 \%$ \\
\hline No & $45 \%$ & $49 \%$ & $50 \%$ & $84 \%$ \\
\hline \multicolumn{5}{|l|}{ Partisanship } \\
\hline In Party & $65 \%$ & $50 \%$ & $51 \%$ & $62 \%$ \\
\hline Out Party & $33 \%$ & $35 \%$ & $39 \%$ & $83 \%$ \\
\hline \multicolumn{5}{|l|}{ State Control } \\
\hline Republican & $51 \%$ & $36 \%$ & $49 \%$ & $80 \%$ \\
\hline Democrat & $24 \%$ & $39 \%$ & $37 \%$ & $81 \%$ \\
\hline Split & $38 \%$ & $55 \%$ & $46 \%$ & $85 \%$ \\
\hline \multicolumn{5}{|l|}{ State Bias } \\
\hline States with bias & $26 \%$ & $38 \%$ & $37 \%$ & $84 \%$ \\
\hline States without bias & $38 \%$ & $52 \%$ & $47 \%$ & $84 \%$ \\
\hline \multicolumn{5}{|l|}{ Final Line Drawer } \\
\hline Legislature & $25 \%$ & $39 \%$ & $38 \%$ & $82 \%$ \\
\hline Partisan Comm. & $30 \%$ & $51 \%$ & $36 \%$ & $82 \%$ \\
\hline Commission & $45 \%$ & $46 \%$ & $57 \%$ & $90 \%$ \\
\hline Courts & $49 \%$ & $52 \%$ & $50 \%$ & $87 \%$ \\
\hline
\end{tabular}

Questions, respectively, are: CCES 30, Pew 52, CCES 32, and CCES 31. Data are weighted. 
districting initiative or protracted litigation (see notes 22 and 23) were much less likely to believe that the redistricting is done fairly, a result that was strongly significant in our regressions (see Tables B1 and B2). A Field Poll conducted in one such state (California) prior to a 2005 initiative revealed similar feelings in response to a more loaded question. Asked "do you feel that the way the state's district lines were redrawn after the last census was generally fair and balanced, or were they redrawn to give the incumbent party an unfair advantage when running for election in each district?," $43 \%$ of registered voters stated that the lines gave an unfair advantage to the majority party whereas only $18 \%$ found them to be fair and balanced (DiCamillo and Field 2005c, 2).

We also see significant divergences in opinion on various metrics of partisanship. First, in states where one party controls the government, we observe striking differences based on party. We code respondents of the same party that controls the government as the "in party" and those of the opposite party as "out party." ${ }^{34}$ Asked whether they believe redistricting is done fairly, respondents from the in party were about twice as likely to say "Yes" than "No." Conversely, respondents from the out party answered "No" about twice as often as "Yes." This result was occasionally significant in our regressions (see Tables B1 and B3). ${ }^{35}$

These variables should be interpreted alongside another-whether a state has a unified or divided government-because "in" and "out" parties only exist where there is a unified government. ${ }^{36}$ In states where the governor and the legislature are divided in some way, the two parties will need to strike a deal to pass a redistricting plan. If a state government is entirely controlled by the same party, however, there is no need to bargain for a fairer map. That said, it is also possible that the bargaining process itself results in a more raucous debate, which displeases voters. ${ }^{37}$ On this metric, we find that respondents from Republican-controlled states were twice as likely as those in Democratic states to think that the process was fair, and people in states with divided government were in between the two. ${ }^{38}$

Relatedly, we ask if partisan bias in the resulting district maps affects public opinion. We have bias data for only 26 states and, accordingly, our number of observations $(N)$ decreases significantly for this analysis. Our measure of bias represents the expected number of seats that Democrats would win with exactly $50 \%$ of the vote. ${ }^{39}$ For instance, a bias measure of $6 \%$ means that if Democrats receive $50 \%$ of the vote, they would be expected to capture $56 \%$ of the legislative seats. A negative value means that the bias favors Republicans. To account for noise in the estimates, we code states as "biased" if both houses ${ }^{40}$ were biased in either direction by $5 \%$ or more.

With respect to perceptions about fairness, Table $5 \mathrm{~A}$ shows that voters in states with biased plans were somewhat less likely to find the process fair$13 \%$ versus $20 \%$ in other states - and were more likely to label it as unfair. These differences were not statistically significant in regressions displayed in Appendix B. Bias, however, is highly correlated with the previous variable (whether a state has a divided government), because states with divided gov-

${ }^{34}$ State party control is based on post-2000 election results from $<$ http://www.ncsl.org/programs/legismgt/statevote/state vote $2000 . h t m>$ (state legislatures) and < http://www.ncsl.org/ programs/legismgt/statevote/govParty_post2000.htm $>$ (state governorship). These data were then combined with respondent's party to create flags for in or out party. We do not consider Independents or minor parties here.

35 "In party" is significant.

${ }^{36}$ We use data about partisan composition following the 2000 election, which is the time when most district lines were drawn following the census. Legislative data by state are from $<$ http://www.ncsl.org/programs/legismgt/statevote/statevote 2000 .htm $>$ and governorship data are from $<$ http://www.ncsl. org/programs/legismgt/statevote/govParty_post2000.htm $>$. Though not reported here, we have also gathered data about state government composition in 2005 , immediately preceding the surveys.

${ }^{37}$ In light of this thinking, our regressions only employ a flag for whether the state has a divided government or not. In other words, we do not include a flag for either Republican-controlled or Democrat-controlled states despite presenting percentages for these states in Tables 5A and 5B. Here, we are most interested in whether any required bargaining results in a redistricting map that voters perceive as fairer. Accordingly, we only include a flag for so-called split states in our regressions.

${ }^{38}$ A dummy variable for states with divided government was never significant in the regressions reported in Appendix B for CCES's question on fairness (or CCES questions about the courts and preferred line drawing authority). We also ran the same regressions from Appendix B with "split state" as the only geographic variable, and the results were the same. It was not a significant predictor of opinion.

${ }^{39}$ Our measure of bias is based on 2002 estimates produced by Bruce Cain and John Hanley (see Ansolabehere, Fougere, and Persily 2010).

${ }^{40}$ We also have coded a bias variable if only one house is biased and the other is not. Here, we display results for bias in both houses so as to capture more extreme instances of bias. Running the same regressions in Tables B3 and B4 with the more mild bias measurement, it was not significant for any regressions on CCES or Pew data. 
ernment are much less likely to show bias. Accordingly, the effect of bias, if any, may be captured elsewhere in the regressions.

Finally, for the same subset of 26 states, we have data on which body was responsible for drawing the final plan-the legislature, an independent commission, a bipartisan commission, ${ }^{41}$ a partisan commission, or the courts (see Ansolabehere, Fougere, and Persily 2010). Table 5A shows that in states with non-partisan line drawers - that is, where done by the courts or a commission-more people found the process to be fair and fewer found it to be unfair than in states utilizing the legislature or a partisan commission. ${ }^{42}$

Satisfaction. Satisfaction with the redistricting process is related, but not identical to, whether the process is perceived as fair. It is, therefore, not surprising that here we find many parallels with the prior section, but also some differences and fewer distinctions among voters. To begin, when the Pew Center asked if people were satisfied or dissatisfied with the way district lines are drawn overall, responses were basically split. Thirteen percent of respondents were satisfied and fourteen percent were not.

We first consider expressions of satisfaction. Most significantly, we find greater evidence of a division between respondents in unified versus divided government states. In particular, in states where both parties control at least one branch of the government, Americans report higher satisfaction with the redistricting process. This result is statistically significant in regressions in Tables B1 and B3 ${ }^{43}$ Similarly, we see greater satisfaction among members of the "in party" than among members of to the "out party," 44 among respondents in states without biased maps, and among those in states where a body other than the (self-interested) legislature drew district lines. Because these variables are all related to whether there is a unified government, it is again not too surprising that the latter observations were not significant in the regressions. The story, however, is the same: respondents appear more satisfied with redistricting when they are on the winning side and when partisanship is less likely to dominate the process.

With respect to dissatisfaction, the same metrics yield opposite results. Pew followed up with the 294 individuals who expressed dissatisfaction with the process by asking the particular reason for that feeling. The question was open-ended, with questioners allowed to probe only for clarity. Pew then coded twelve responses. Similar to other responses, dissatisfied respondents blamed gerrymandering generally $(6 \%)$, incumbency protection $(10 \%)$, and too much partisanship (10\%). An additional two percent stated that an independent panel was needed to draw districts. Remaining answers were quite broad. ${ }^{45}$

These general findings continue with our more specific variables. First, we again find frustration among minority party members: members of the "out party" are more dissatisfied than satisfied and considerably more dissatisfied than members of the "in party." Moreover, respondents in states without a divided government were more likely to be dissatisfied. ${ }^{46}$ People from states with biased maps also reported a higher level of dissatisfaction. Finally, the greatest level of dissatisfaction (and the greatest disparity between dissatisfaction and satisfaction) came from states where the legislature drew the lines.

Although evidence of dissatisfaction largely parallels our other findings, one group that found redistricting to be unfair did not report significantly different levels of satisfaction. In particular, people in states experiencing a recent redistricting initiative or controversy were only slightly more likely to be dissatisfied with the redistricting process. This variable, moreover, was not significant in the regressions. Accordingly, the data indicate that while controversial or high-profile redistricting caused re-

${ }^{41}$ We group independent and bipartisan commissions together. ${ }^{42}$ These variables are not significant in Table B3, but their impact again may be captured elsewhere. As with the variable for divided government, these institutional variables capture bias because bias is lower in states where the legislature is not the final authority for redistricting. Out of the 26 states for which we have data, 8 of the 11 exhibiting bias were states where the legislature drew the final lines.

43 The variable is labeled as "Split State."

${ }^{44}$ Like the average respondent, a respondent identifying with the "in party" was equally likely to be satisfied as he was to be dissatisfied."

45 They were: too complicated/unclear process $(4 \%)$, other (misc) $(15 \%)$, other (misunderstood question) $(13 \%)$, everything (12\%), unfair distribution of resources $(6 \%)$, the public has no say $(2 \%)$, don't know/refused $(14 \%)$. Six percent cited the use of racial criteria.

${ }^{46}$ As noted above, the variable for divided government ("Split State") was strongly significant in the regressions in Appendix B. 
spondents to find the process more unfair, they were not significantly less satisfied with the end result. ${ }^{47}$

Our findings track those reported by others analyzing the Pew data, especially with respect to electoral winners and losers. Bowler and Donovan find that Americans who hope their members of Congress are re-elected are more satisfied with districting. On dissatisfaction, differences were stark but not surprising: a respondent who holds no unfavorable views about politics, lives where her party usually wins, and does not think elected officials draw lines was not likely to be dissatisfied with the redistricting process. In contrast, a respondent with the opposite responses on all three questions was much more likely to be dissatisfied. (Bowler and Donovan 2009, 12, 17). In a cut of the data that we do not replicate, McDonald considers winners and losers in the high-profile states of California, Ohio, Texas and finds that $21.6 \%$ of those on the losing side expressed dissatisfaction compared to just $9.1 \%$ of the winners (McDonald 2007, 15).

Attitudes toward institutions. As should be clear from the previous two sections, attitudes toward institutions involved in redistricting are closely related to perceptions about the process more generally. People are more likely to report fairness and satisfaction where disinterested actors are in charge or where some bargaining should occur. Here, we consider opinions about institutions specifically.

First, CCES asked respondents whether they would prefer that redistricting be done by a legislature or an independent commission. Overall, paralleling their perception that the process is not fair, people expressed strong disapproval of legislative control of the redistricting process. Although most states entrust legislatures with line-drawing authority (National Conference of State Legislatures 2009, 178-179), only ten percent of Americans would prefer that redistricting be done by that body. By contrast, forty-nine percent would prefer that an independent commission were in charge.

A closer look at partisanship reveals somewhat predictable feelings on this question. Members of the in party preferred an independent commission considerably less often than the average American and reported a preference for the self-interested legislature at a rate twice that of the general population. Respondents from the out party, by contrast, shared the same opinion as most Americans, with
$49 \%$ preferring an independent commission and only $10 \%$ preferring the legislature. Thus, even though the surveys were taken several years after the lines were drawn in most states, we find some fairly strong evidence of both approval from winners and opposition among losers to the process in states with a unified government. ${ }^{48}$

These data parallel analyses of initiatives in California and Ohio in 2005 to move line-drawing authority from the legislature to a commission. In a recent study, Tolbert, Smith, and Green seek to explain why both initiatives lost despite seemingly strong support for independent commissions in post-election surveys. At least part of the explanation, they argue, is that self-interested voters act strategically, and winners prefer the status quo even if they like the idea of commissions in the abstract. Most voters are "winners" at the district level and, as such, are more likely to favor the status quo. ${ }^{49}$ Losers at both the state and district level (so-called "dual losers") were most likely to support reform, but they only constitute a minority of voters (Tolbert, Smith, and Green 2009). Likewise, Field Polls conducted in California throughout 2005 show that Democrats and liberals (the winners) opposed reform whereas Republicans and conservatives (the losers) were consistently in favor of divesting the legislature of its authority (DiCamillo and Field, 2005a, $2005 \mathrm{~b}, 2005 \mathrm{c}$ ). In 2008, California considered another redistricting initiative, and Republicans and conservatives again favored the reform more than Democrats and liberals (although the latter group now expressed plurality support ${ }^{50}$ (DiCamillo and Field 2008a).

\footnotetext{
${ }^{47}$ Our expanded list of states again yields results analogous to McDonald's in this regard (see notes 20-25; McDonald 2007, 14). ${ }^{48}$ Despite the strong differences in Tables $5 \mathrm{~A}$ and $5 \mathrm{~B}$, the variables "in party" and "out party" are not significant in our regression on preferred authority in Tables B2 and B4.

${ }^{49}$ District-level losers are defined as individuals whose party identification does not coincide with at least two of their three representatives (state House, state Senate, and U.S. Congress). ${ }^{50}$ Proposition 11 barely succeeded, and there are many possible explanations for why it passed this time. Perhaps the most straightforward is that 2008 was a general election year and 2005 was not. Turnout for the presidential election and the controversial Proposition 8 may have favored Republicans and conservatives as compared to Democrats by just enough. It is, however, unclear why Democrats shifted from strong disapproval in 2005 to plurality support for reform shortly before Election Day in 2008. There may have been some spillover from voters' increased frustration with the Democratic legislature over the budget crisis or rising frustration with government overall or simply a slightly different subset of the electorate voting.
} 
Other variables in the Pew and CCES surveys, however, do not add much to the analysis of attitudes towards commissions and legislatures. Respondents in states with divided government and states with biased plans showed only a slightly higher preference for independent commissions than did those in states with unified government or non-biased plans. Similarly, and somewhat surprisingly, states experiencing a recent controversy or initiative did not correlate with a significantly stronger preference for independent commissions over legislatures.

With respect to the courts, of course, partisanship and incumbency issues are more complicated. Some states that elect judges do so in non-partisan elections, which might be thought to diminish fears of partisan plans. ${ }^{51}$ On the other hand, in states that hold partisan elections for judges, one might expect some concerns about partisanship affecting courts' role in the redistricting process. Reflective of this more nuanced picture, the data reveal more satisfaction with the courts as opposed to the process overall. CCES survey respondents, of whom a strong majority felt that redistricting was not done fairly, were split on their satisfaction with the courts' job in settling disputes. Twenty-one percent thought the courts did a good or very good job (19\% and $2 \%$, respectively), while only slightly more, twenty-seven percent, found that the courts do a poor or a very poor job (18\% and $9 \%$, respectively).

Only a few variables help explain opinions about the courts and the redistricting process. First, in states where redistricting was controversial or the subject of an initiative, CCES respondents exhibited a much lower opinion of courts' involvement in redistricting disputes. Second, opinions of the courts are somewhat lower in states with biased redistricting plans. This may reflect a general distaste for the redistricting process more than a specific concern about the courts.

Finally, we find that, in the 26 states for which we know the final line-drawing authority, respondents prefer the authority with which they are familiar. In states where courts drew the final lines, opinion was split on whether the courts did a good or poor job. Compared with partisan-controlled states, in which more voters stated that the courts do a poor job, this provides some evidence that the courts were able to win over some support where they participated directly in redistricting. ${ }^{52}$ Finally, Table 5B shows that, among those with an opinion, respondents in states where commissions control the process are more likely to prefer a commission. ${ }^{53}$

\section{Related distaste: Politicians}

As a final matter, we consider the relationship between voters' opinions on politicians generally and their attitudes concerning the redistricting process. As redistricting implicates issues of partisanship and incumbency, we ask to what extent low public opinion can be explained by less favorable attitudes towards politicians (Persily and Lammie 2004; Persily 2002). ${ }^{54}$ To test this idea, we look at approval levels for Congress and the President, as well as opinions of political independents. ${ }^{55}$ Tables $6 \mathrm{~A}$ and $6 \mathrm{~B}$ give the percentages.

As expected, the tables reveal a strong relationship between public attitudes toward politicians and redistricting. Although this trend is observable for each variable presented ${ }^{56}$ it is most noticeable with respect to approval of the legislature - the body directly affected by redistricting plans. As approval levels decrease, so too do opinions that redistricting is fair or done in a satisfactory way. Further, as opinions of Congress decrease, voters were steadily more likely to prefer that an independent commission, and not the legislature, be responsible for drawing election districts. Indeed, in each of the regressions presented in Tables B1, B2, and B3, the variable for congressional approval is a statistically significant predictor of these opinions. Thus, on top of prior explanations given in this Part, we find that

${ }^{51}$ For specific information about the methods of selecting appellate and trial court judges by state, see (Rottman and Strickland 2006, 25-28, 33-39).

${ }^{52}$ In Table B4, however, only the flag for "Commission" is significant in the refined regression.

${ }^{53}$ Table B4 shows that partisan commission and commission were significant in the regressions on preferred authority.

${ }^{54}$ Using the same Pew data, Bowler and Donovan analyze how attitudes towards redistricting relate to negative attitudes towards politicians generally and "instrumental evaluations." They find, for example, greater dissatisfaction among respondents who dislike politics, whose party generally loses, and who think that elected officials draw district lines (Bowler and Donovan 2009).

${ }^{55}$ Because a lack of party affiliation is a strong indicator of distaste for politicians, we include these percentages in Tables $6 \mathrm{~A}$ and $6 \mathrm{~B}$. A dummy variable is not, however, included in the regressions in Appendix B. This was done because (1) when included, it was insignificant and (2) including it had an effect on Republican and Democrat dummies given that there were few respondents in non-traditional parties.

${ }^{56}$ Despite the indication in Tables 6A and 6B that lower presidential approval is associated with lower opinions about redistricting, this variable is rarely significant in the regressions in Appendix B. 
FOUGERE ET AL.

Table 6A. Correlation With Opinion About Politicians (All Respondents)

\begin{tabular}{|c|c|c|c|c|c|c|c|c|}
\hline & \multicolumn{2}{|c|}{$\begin{array}{l}\text { Think districting } \\
\text { done fairly }\end{array}$} & \multicolumn{2}{|c|}{$\begin{array}{l}\text { Satisfied with } \\
\text { the way } \\
\text { lines drawn }\end{array}$} & \multicolumn{2}{|c|}{$\begin{array}{l}\text { Courts do a _ job } \\
\text { settling disputes }\end{array}$} & \multicolumn{2}{|c|}{$\begin{array}{c}\text { Prefer an independent } \\
\text { commission or } \\
\text { legislature }\end{array}$} \\
\hline & Yes & No & Yes & No & Good/V good & Poor $/ V$ poor & Comm. & Leg. \\
\hline \multicolumn{9}{|l|}{ Congress Approval } \\
\hline Approve Strongly & $47 \%$ & $0 \%$ & $20 \%$ & $16 \%$ & $11 \%$ & $36 \%$ & $0 \%$ & $54 \%$ \\
\hline Approve & $38 \%$ & $17 \%$ & $17 \%$ & $9 \%$ & $39 \%$ & $21 \%$ & $40 \%$ & $13 \%$ \\
\hline Neither & $18 \%$ & $20 \%$ & $6 \%$ & $7 \%$ & $18 \%$ & $14 \%$ & $31 \%$ & $8 \%$ \\
\hline Disapprove & $18 \%$ & $31 \%$ & $11 \%$ & $17 \%$ & $19 \%$ & $31 \%$ & $52 \%$ & $11 \%$ \\
\hline Disapprove Strongly & $13 \%$ & $51 \%$ & $8 \%$ & $30 \%$ & $21 \%$ & $36 \%$ & $69 \%$ & $9 \%$ \\
\hline \multicolumn{9}{|l|}{ Presidential Approval } \\
\hline Strongly Approve & $34 \%$ & $21 \%$ & $16 \%$ & $12 \%$ & $20 \%$ & $34 \%$ & $37 \%$ & $14 \%$ \\
\hline Somewhat Approve & $25 \%$ & $27 \%$ & $16 \%$ & $12 \%$ & $26 \%$ & $23 \%$ & $43 \%$ & $14 \%$ \\
\hline Somewhat Disapprove & $17 \%$ & $23 \%$ & $12 \%$ & $18 \%$ & $22 \%$ & $27 \%$ & $40 \%$ & $11 \%$ \\
\hline Strongly Disapprove & $12 \%$ & $41 \%$ & $12 \%$ & $18 \%$ & $20 \%$ & $27 \%$ & $61 \%$ & $6 \%$ \\
\hline Not sure & $5 \%$ & $14 \%$ & $8 \%$ & $7 \%$ & $3 \%$ & $0 \%$ & $9 \%$ & $4 \%$ \\
\hline \multicolumn{9}{|l|}{ Partisanship } \\
\hline Independents & $13 \%$ & $39 \%$ & $10 \%$ & $14 \%$ & $21 \%$ & $29 \%$ & $56 \%$ & $7 \%$ \\
\hline
\end{tabular}

Questions, respectively, are: CCES 30, Pew 52, CCES 32, and CCES 31. Data are weighted. For Pew Center poll, the precise wording of responses on congressional approval is Very Favorable, Mostly Favorable, Can't Rate, Mostly Unfavorable, Very Unfavorable. In the CCES survey, the responses "Approve Strongly" under congressional approval and "Not Sure" under presidential approval represented very small percentages of the sample, which explains the odd figures. With respect to presidential approval, Pew only gives two possible responses, Approve or Disapprove. Accordingly, those percents are duplicated twice under Strongly and Somewhat. With the exception of the respective questions from the studies, these facts hold true for Table $6 \mathrm{~B}$ as well.

views about politicians generally are a strong indicator of views on redistricting.

\section{CONCLUSIONS}

Our look at public opinion and redistricting has occurred in several stages. We began with the over- whelmingly low salience of redistricting in general. Although some factors help to explain these datavoters in states where redistricting initiatives and controversies were more high-profile, for instance, are more knowledgeable-there is no escaping that one of the primary takeaways from our study is that Americans are not well-informed and do not often have an opinion when it comes to drawing election districts.

Table 6B. Correlation with Opinion about Politicians (Respondents With Options)

\begin{tabular}{|c|c|c|c|c|}
\hline & $\begin{array}{l}\text { Think districting } \\
\text { done fairly }\end{array}$ & $\begin{array}{l}\text { Satisfied with the } \\
\text { way lines drawn }\end{array}$ & $\begin{array}{l}\text { Courts do good/v } \\
\text { good job } \\
\text { settling disputes }\end{array}$ & $\begin{array}{l}\text { Prefer an } \\
\text { independent } \\
\text { commission }\end{array}$ \\
\hline \multicolumn{5}{|l|}{ Congress Approval } \\
\hline Approve Strongly & $100 \%$ & $56 \%$ & $24 \%$ & $0 \%$ \\
\hline Approve & $69 \%$ & $67 \%$ & $65 \%$ & $76 \%$ \\
\hline Neither & $47 \%$ & $50 \%$ & $57 \%$ & $79 \%$ \\
\hline Disapprove & $37 \%$ & $39 \%$ & $37 \%$ & $82 \%$ \\
\hline Disapprove Strongly & $20 \%$ & $21 \%$ & $36 \%$ & $89 \%$ \\
\hline \multicolumn{5}{|l|}{ Presidential Approval } \\
\hline Strongly Approve & $62 \%$ & $58 \%$ & $37 \%$ & $72 \%$ \\
\hline Somewhat Approve & $48 \%$ & $58 \%$ & $53 \%$ & $75 \%$ \\
\hline Somewhat Disapprove & $43 \%$ & $39 \%$ & $45 \%$ & $79 \%$ \\
\hline Strongly Disapprove & $23 \%$ & $39 \%$ & $42 \%$ & $90 \%$ \\
\hline Not sure & $25 \%$ & $55 \%$ & $100 \%$ & $67 \%$ \\
\hline \multicolumn{5}{|l|}{ Partisanship } \\
\hline Independents & $26 \%$ & $41 \%$ & $43 \%$ & $89 \%$ \\
\hline
\end{tabular}


Analyzing the structure of public opinion where it does exist, we find a little something for everyone (or every theory). Demographic characteristics tell part of the story, with minorities less likely than whites to label the redistricting process as fair, for example. Opinions also differentiate along partisan and ideological lines. And of course, opinions on drawing district lines to elect members of Congress are strongly related to opinions about Congress itself.

Our primary focus was on partisanship and incumbency protection, and on that topic, we found that Americans think rationally about redistricting. Those who identify with the party in control of a state's government are more likely to be satisfied and consider fair the redistricting process. A divided government also left voters more satisfied with the redistricting process. Respondents were less likely to view the redistricting process as fair or to express satisfaction with it if they lived in states where final district lines were drawn by a partisan body and in states where the map itself is biased in one party's favor. Opinions about institutional actors paralleled these observations, leading us to conclude that, among the minority of voters with an opinion on the question, voters generally favor a redistricting process that requires bargaining and is run by disinterested actors.

\section{REFERENCES}

Ansolabehere, Stephen and Persily, Nathaniel. 2008. Vote Fraud in the Eye of the Beholder: The Role of Public Opinion in the Challenge to Voter Identification Requirements. Harvard Law Review. 121:1742-44.

- . 2009. Public Opinion and Election Law Controversies Past and Present. < http://volokh.com/2009/11/17/public-opinionand-election-law-controversies-past-and-present/>.

Ansolabehere, Stephen, Fougere, Joshua and Persily, Nathaniel. 2010. bias_resp_better_040507.xls (Data on file with authors).

Baker v. Carr. 1962. 369 U.S. 186.

Bowler, Shaun and Donovan, Todd. 2009. Voter Perceptions of Elections and Electoral Competition. (Manuscript prepared for Midwest Political Science Association 2009 Conference, on file with authors).

Colegrove v. Green. 1946. 328 U.S. 549.

Cooperative Congressional Election Studies (CCES). 2006a. $<$ http://web.mit.edu/polisci/portl/cces/commoncontent.html $>$. -.2006b. MIT_CCES_v4.doc (Data on file with authors).

DiCamillo, Mark and Field, Mervin. 2008a. The Field Poll, Release \# 2292.
< http://field.com/fieldpollonline/subscribers/R1s2292.pdf>. - . 2008b. The Field Poll, Release \# 2280.

$<$ http://field.com/fieldpollonline/subscribers/RIs2280.pdf > .

- . 2005a. The Field Poll, Release \# 2168.

$<$ http://field.com/fieldpollonline/subscribers/RLS2168.pdf>.

- . 2005b. The Field Poll, Release \# 2159.

$<$ http://field.com/fieldpollonline/subscribers/RLS2159.pdf>.

- . 2005c. The Field Poll, Release \# 2153.

$<$ http://field.com/fieldpollonline/subscribers/RLS2153.pdf>.

Issacharoff, Samuel et al. 2007. The Law of Democracy: Legal Structure of the Political Process 132-33 (3d. ed.).

McDonald, Michael P. 2008. "Legislative Redistricting." In Democracy in the States: Experiments in Election Reform, ed. Bruce E. Cain et al., 147. Brookings Institution Press. - . 2007. Where the Ivory Tower Meets the Road: Voter Perceptions of Electoral Competition. (Manuscript prepared for "2008 and Beyond: The Future of Election and Ethics Reform in the States" conference, on file with authors).

National Conference of State Legislatures. 2009. Redistricting Law 2010, 178-79. < http://www.senate.mn/departments/ scr/redist/Red2010/Redistricting_Law_2010.pdf $>$.

Persily, Nathaniel. 2002. In Defense of Foxes Guarding Henhouses: The Case for Judicial Acquiescence to IncumbentProtecting Gerrymanders. Harvard Law Review 115:593.

Persily, Nathaniel and Lammie, Kelli. 2004. Perceptions of Corruption and Campaign Finance: When Public Opinion Determines Constitutional Law. University of Pennsylvania Law Review 153:119.

Pew Research Center. 2006a. Most Have Heard Little or Nothing About Redistricting Debate: Lack of Competition in Elections Fails to Stir Public (October 27). < http://peoplepress.org/dataarchive/>.

-. 2006b. 26069.Methodology.doc.

Roper Center for Public Opinion Research, The. 2006. $<$ http://www .ropercenter.uconn.edu/data_access/ipoll/ipoll. html $>$.

Rottman, David B. and Strickland, Shauna M. 2006. U.S. Dep't of Justice, State Court Organization, 2004, 25-28, 33-39. $<$ http://bjs.ojp.usdoj.gov/content/pub/pdf/sco04.pdf > .

Stephanopoulos, Nicholas. 2007. Reforming Redistricting: Why Popular Initiatives to Establish Redistricting Commissions Succeed or Fail. Journal of Law and Politics 23:331

Tolbert, Caroline J., Smith, Daniel A., and Green, John C. 2009. Strategic Voting and Legislative Redistricting Reform: District and Statewide Representational Winners and Losers. Political Research Quarterly 62(1): 92-109.

Address correspondence to: Nathaniel Persily 435 West 116th Street Columbia Law School New York, NY 10025

E-mail: npersily@gmail.com 


\section{APPENDIX A: REGRESSIONS TESTING LACK OF OPINION}

Table A1. Pew Study Question 50

\begin{tabular}{lcr}
\hline Variables & Saturated & Pared down \\
\hline Demographics & & \\
White & $0.01(0.11)$ & $0.02(0.11)$ \\
Black & $-0.05(0.14)$ & $-0.04(0.14)$ \\
Hispanic & $0.09(0.14)$ & $0.09(0.14)$ \\
Female & $0.15(0.05)^{*}$ & $0.15(0.05)^{*}$ \\
Age & $0.00(0.00)^{*}$ & $0.00(0.00)^{*}$ \\
Education & $-0.08(0.02)^{*}$ & $-0.08(0.02)^{*}$ \\
Income & $0.00(0.01)$ & $-0.21(0.05)^{*}$ \\
Geographic Variables & $-0.21(0.05)^{*}$ & \\
Recent Issue State & $-0.01(0.02)$ & $-0.10(0.05)^{*}$ \\
Census Region & $-0.09(0.06)$ & \\
Political Orientation & $0.01(0.07)$ & \\
Democrat & $0.00(0.03)$ & \\
Republican & $-0.04(0.07)$ & $0.16(0.03)^{*}$ \\
Ideology & $0.03(0.07)$ & .12 \\
In Party & $0.16(0.03)^{*}$ & 1,268 \\
Out Party & .13 & \\
News Attention & 1,268 & \\
Elections & & \\
$R^{2}$ & &
\end{tabular}

The dependent variable, how much respondent has heard about the redistricting debate, is ordered: a lot (equal to 1), a little (equal to 2), and nothing (equal to 3). Thus, a negative relationship corresponds to a greater likelihood respondent has heard more about the debate as the independent variable increases. Coefficients are from a linear regression to facilitate interpretation, but order probits were also run. Coefficients are significantly different from zero at $* p<.05$. 
Table A2. Questions Regarding Fairness And SAtisfaction

\begin{tabular}{|c|c|c|c|}
\hline Variables & Done Fairly? & Satisfied? & Courts' Job \\
\hline \multicolumn{4}{|l|}{ Demographics } \\
\hline White & $-0.16(0.21)$ & $-0.07(0.21)$ & $0.30(0.21)$ \\
\hline Black & $-0.57(0.32)$ & $-0.17(0.26)$ & $0.07(0.33)$ \\
\hline Hispanic & $-0.48(0.29)$ & $-0.13(0.31)$ & $0.24(0.30)$ \\
\hline Female & $-0.55(0.12)^{*}$ & $-0.24(0.10) *$ & $0.43(0.12)^{*}$ \\
\hline Age & $0.00(0.00)$ & $0.01(0.00)^{*}$ & $0.00(0.00)$ \\
\hline Education & $0.24(0.06)^{*}$ & $0.07(0.05)$ & $-0.10(0.06)$ \\
\hline Income & $0.04(0.02)^{*}$ & $0.01(0.03)$ & $-0.04(0.02)$ \\
\hline \multicolumn{4}{|l|}{ Geographic Variables } \\
\hline Recent Issue State & $0.10(0.12)$ & $-0.01(0.10)$ & $-0.09(0.12)$ \\
\hline Region & $0.11(0.05)$ & $0.06(0.05)$ & $-0.10(0.06)$ \\
\hline Political Orientation & & & $0.19(0.18)$ \\
\hline Democrat & $0.10(0.17)$ & $0.14(0.14)$ & $0.00(0.17)$ \\
\hline Republican & $0.09(0.17)$ & $0.00(0.14)$ & $-0.03(0.06)$ \\
\hline Ideology & $-0.04(0.06)$ & $-0.04(0.06)$ & $-0.21(0.19)$ \\
\hline In Party & $0.22(0.20)$ & $-0.01(0.15)$ & $-0.10(0.20)$ \\
\hline Out Party & $-0.09(0.20)$ & $-0.10(0.15)$ & \\
\hline \multicolumn{4}{|l|}{ News Attention } \\
\hline Elections & N/A & $-0.30(0.06)^{*}$ & N/A \\
\hline Log Likelihood & -481.6 & -724.2 & -499.3 \\
\hline Pseudo R2 & .09 & .07 & .06 \\
\hline$N$ & 764 & 1,279 & 764 \\
\hline
\end{tabular}

For the first and second columns, probit regressions were run on a binary variable where respondents express a positive or negative opinion (value 1) or do not (value 0). Conversely, for the third column, probit regressions were run on a binary variable where respondents express a positive or negative opinion (value 0) or do not (value 1). Coefficients are significantly different from zero at $* p<.05$.

Table A3. Questions Regarding Line-Drawing Authority

\begin{tabular}{|c|c|c|}
\hline Variables & Preferred Authority? & Know Who Draws? \\
\hline \multicolumn{3}{|l|}{ Demographics } \\
\hline White & $-0.20(0.24)$ & $0.00(0.20)$ \\
\hline Black & $-0.55(0.34)$ & $-0.28(0.27)$ \\
\hline Hispanic & $-0.33(0.33)$ & $-0.13(0.29)$ \\
\hline Female & $-0.47(0.12)^{*}$ & $0.32(0.09)^{*}$ \\
\hline Age & $0.01(0.00)$ & $0.00(0.00)$ \\
\hline Education & $0.32(0.07)^{*}$ & $-0.02(0.05)$ \\
\hline \multirow[t]{2}{*}{ Income } & $0.02(0.02)$ & $-0.01(0.02)$ \\
\hline & & $0.05(0.13)$ \\
\hline \multicolumn{3}{|l|}{ Geographic Variables } \\
\hline Recent Issue State & $0.05(0.13)$ & $-0.27(0.10)^{*}$ \\
\hline Region & $0.07(0.06)$ & $-0.01(0.05)$ \\
\hline \multicolumn{3}{|l|}{ Political Orientation } \\
\hline Democrat & $-0.09(0.18)$ & $0.25(0.13)^{*}$ \\
\hline Republican & $-0.11(0.18)$ & $-0.01(0.13)$ \\
\hline Ideology & $-0.03(0.07)$ & $0.00(0.06)$ \\
\hline In Party & $0.13(0.20)$ & $0.15(0.14)$ \\
\hline Out Party & $0.17(0.20)$ & $0.12(0.14)$ \\
\hline \multicolumn{3}{|l|}{ News Attention } \\
\hline Elections & N/A & $0.21(0.05)^{*}$ \\
\hline Log Likelihood & -458.2 & -810.6 \\
\hline Pseudo $R^{2}$ & .09 & .05 \\
\hline$N$ & 764 & 1,279 \\
\hline
\end{tabular}

For the first column, probit regressions were run on a binary variable where respondents express a preference for a commission or a legislature (value 1) or do not (value 0). For the second column, probit regressions were run on a binary variable where respondents do not know or refuse to answer (value 1) or give a substantive response (value 0 ). Coefficients are significantly different from zero at $* p<.05$. 


\section{APPENDIX B: REGRESSIONS TESTING OPINIONS ON REDISTRICTING}

Our data on state bias and line-drawing authority cover only 26 states. As such, many observations drop out when we include these variables in our regressions. We therefore present results for regressions with all variables except state bias and final line-drawing authority first in Tables B1 and B2. Tables B3 and $\mathrm{B} 4$ (with smaller $\mathrm{N}$ ) then give results from the same regressions with variables for state bias and for who drew the plan added.

Two additional notes are necessary. First, in Tables B1 and B3, we include "No opinion" respondents in our analysis to achieve a higher $N$. The regressions were also run on ordered variables excluding those individuals and the results did not materially change. Second, $F$ tests were run to test whether variables could be dropped from the pared-down models presented.

Table B1. Questions Regarding Fairness and Satisfaction (No Bias Data)

\begin{tabular}{|c|c|c|c|c|}
\hline \multirow[b]{2}{*}{ Variables } & \multicolumn{2}{|c|}{ Done Fairly } & \multicolumn{2}{|c|}{ Satisfied with Process? } \\
\hline & Saturated & Pared down & Saturated & Pared down \\
\hline \multicolumn{5}{|l|}{ Demographics } \\
\hline White & $0.02(0.11)$ & $0.03(0.11)$ & $-0.04(0.07)$ & $-0.03(0.07)$ \\
\hline Black & $-0.10(0.16)$ & $-0.08(0.16)$ & $0.01(0.09)$ & $0.00(0.08)$ \\
\hline Hispanic & $-0.15(0.15)$ & $-0.11(0.15)$ & $-0.01(0.10)$ & $0.01(0.10)$ \\
\hline Female & $0.10(0.06)$ & $0.10(0.06)$ & $-0.08(0.04)^{*}$ & $-0.08(0.03) *$ \\
\hline Age & $0.00(0.00)$ & $0.00(0.00)$ & $0.00(0.00)$ & \\
\hline Education & $-0.05(0.03)$ & $-0.05(0.03)^{*}$ & $0.03(0.02)$ & $0.03(0.02)$ \\
\hline Income & $0.00(0.01)$ & & $0.00(0.01)$ & \\
\hline \multicolumn{5}{|l|}{ Geographic Variables } \\
\hline Recent Issue State & $-0.23(0.06)^{*}$ & $-0.25(0.06)^{*}$ & $0.00(0.04)$ & \\
\hline Split State & $0.09(0.08)$ & & $0.14(0.06)^{*}$ & $0.10(0.03)^{*}$ \\
\hline Region & $-0.01(0.03)$ & & $0.01(0.02)$ & \\
\hline \multicolumn{5}{|l|}{ Political Orientation } \\
\hline Democrat & $0.07(0.10)$ & & $0.04(0.05)$ & \\
\hline Republican & $0.07(0.10)$ & & $0.06(0.06)$ & \\
\hline Ideology & $0.00(0.03)$ & & $0.00(0.02)$ & \\
\hline In Party & $0.36(0.13)^{*}$ & $0.35(0.08)^{*}$ & $0.08(0.08)$ & \\
\hline Out Party & $-0.04(0.13)$ & & $0.03(0.08)$ & \\
\hline \multicolumn{5}{|l|}{ Political (Dis)taste } \\
\hline Congress Approval & $-0.12(0.04)^{*}$ & $-0.12(0.03)^{*}$ & $-0.08(0.02)^{*}$ & $-0.09(0.01)^{*}$ \\
\hline Pres. Approval & $-0.06(0.04)$ & $-0.06(0.03)^{*}$ & $0.02(0.04)$ & \\
\hline \multicolumn{5}{|l|}{ Awareness } \\
\hline Heard of Debate & N/A & N/A & $0.02(0.03)$ & \\
\hline$R^{2}$ & .16 & .15 & .06 & .06 \\
\hline$N$ & 732 & 732 & 1,461 & 1,461 \\
\hline
\end{tabular}

Dependent variables are ordered. For the first column, coded responses are "Yes" (equal to 1), "Not sure" or "No opinion" (equal to 0), "No" (equal to -1). For the second, coded responses are "Satisfied" (equal to 1), "Don’t Know/Refuse" or "No opinion about it" (equal to 0), and "Dissatisfied" (equal to -1). Coefficients are from linear regressions to facilitate interpretation, but order probits were also run. Coefficients are significantly different from zero at $* p<.05$. 
Table B2. Questions Regarding Courts and Line-Drawing Authority (No Bias Data)

\begin{tabular}{|c|c|c|c|c|}
\hline \multirow[b]{2}{*}{ Variables } & \multicolumn{2}{|c|}{ Courts' Job } & \multicolumn{2}{|c|}{ Preferred Authority } \\
\hline & Saturated & Pared down & Saturated & Pared down \\
\hline \multicolumn{5}{|l|}{ Demographics } \\
\hline White & $0.35(0.15) *$ & $0.35(0.15) *$ & $0.04(0.24)$ & $0.01(0.24)$ \\
\hline Black & $0.46(0.27)$ & $0.46(0.26)$ & $-0.17(0.37)$ & $-0.19(0.35)$ \\
\hline Hispanic & $0.50(0.20)^{*}$ & $0.49(0.20)^{*}$ & $-0.24(0.34)$ & $-0.28(0.33)$ \\
\hline Female & $0.06(0.08)$ & $0.07(0.08)$ & $-0.06(0.13$ & $-0.08(0.13)$ \\
\hline Age & $-0.01(0.00)^{*}$ & $-0.01(0.00) *$ & $0.00(0.00)$ & \\
\hline Education & $-0.01(0.04)$ & & $0.15(0.07)^{*}$ & $0.14(0.07)^{*}$ \\
\hline Income & $-0.02(0.01)$ & $-0.02(0.01)$ & $0.05(0.02) *$ & $0.05(0.02)^{*}$ \\
\hline \multicolumn{5}{|l|}{ Geographic Variables } \\
\hline Recent Issue State & $-0.23(0.08)^{*}$ & $-0.26(0.08)^{*}$ & $-0.05(0.13)$ & \\
\hline Split State & $0.03(0.13)$ & & $0.05(0.18)$ & \\
\hline Region & $-0.02(0.04)$ & & $0.00(0.06)$ & \\
\hline \multicolumn{5}{|l|}{ Political Orientation } \\
\hline Democrat & $0.01(0.15)$ & & $-0.05(0.21)$ & \\
\hline Republican & $0.02(0.13)$ & & $0.05(0.21)$ & \\
\hline Ideology & $-0.01(0.05)$ & & $-0.11(0.08)$ & $-0.10(0.08)$ \\
\hline In Party & $0.05(0.20)$ & & $-0.31(0.27)$ & \\
\hline Out Party & $-0.19(0.18)$ & & $0.19(0.27)$ & \\
\hline \multicolumn{5}{|l|}{ Political (Dis)taste } \\
\hline Congress Approval & $-0.11(0.05)^{*}$ & $-0.09(0.04)^{*}$ & $0.16(0.07)^{*}$ & $0.16(0.07)^{*}$ \\
\hline Pres. Approval & $0.03(0.05)$ & & $0.14(0.08)$ & $0.13(0.07)$ \\
\hline Log Likelihood & & & -400.9 & -404.9 \\
\hline Pseudo $R^{2}$ & & & .10 & .09 \\
\hline$R^{2}$ & .08 & .07 & & \\
\hline$N$ & 732 & 732 & 665 & 665 \\
\hline
\end{tabular}

Dependent variables are ordered or binary. For the first column, coded responses are "Very Good" (equal to 2), "Good" (equal to 1), "Not sure" (equal to 0), "Poor" (equal to -1), and "Very Poor" (equal to -2). Coefficients are from linear regressions to facilitate interpretation, but order probits were also run. For the second, coded responses are "Commission" (equal to 1) and "Legislature" or "Not Sure" (equal to 0). "No opinion" responses are excluded. Probit regressions were run on this binary variable. Coefficients are significantly different from zero at $* p<.05$. 
FOUGERE ET AL.

Table B3. Questions Regarding Fairness and Satisfaction (With Bias Data)

\begin{tabular}{|c|c|c|c|c|}
\hline \multirow[b]{2}{*}{ Variables } & \multicolumn{2}{|c|}{ Done Fairly } & \multicolumn{2}{|c|}{ Satisfied with Process? } \\
\hline & Saturated & Pared down & Saturated & Pared down \\
\hline \multicolumn{5}{|l|}{ Demographics } \\
\hline White & $-0.03(0.13)$ & $-0.03(0.12)$ & $-0.09(0.08)$ & $-0.08(0.07)$ \\
\hline Black & $-0.01(0.18)$ & $-0.01(0.18)$ & $0.00(0.10)$ & $-0.02(0.09)$ \\
\hline Hispanic & $-0.19(0.17)$ & $-0.19(0.16)$ & $-0.03(0.11)$ & $-0.01(0.11)$ \\
\hline Female & $0.02(0.07)$ & $0.02(0.07)$ & $-0.07(0.04)$ & $-0.06(0.04)$ \\
\hline Age & $-0.01(0.00)^{*}$ & $-0.01(0.00)^{*}$ & $0.00(0.00)$ & \\
\hline Education & $-0.06(0.04)$ & $-0.07(0.03)^{*}$ & $0.02(0.02)$ & \\
\hline Income & $0.00(0.01)$ & & $0.00(0.01)$ & \\
\hline \multicolumn{5}{|l|}{ Geographic Variables } \\
\hline Recent Issue State & $-0.14(0.10)$ & $-0.13(0.07)$ & $0.00(0.06)$ & \\
\hline Split State & $0.02(0.10)$ & & $0.17(0.07)^{*}$ & $0.12(0.04)^{*}$ \\
\hline State Bias & $-0.01(0.12)$ & & $0.02(0.06)$ & \\
\hline Commission & $0.26(0.14)$ & $0.23(0.09)^{*}$ & $0.02(0.08)$ & \\
\hline Courts & $0.25(0.13)$ & $0.23(0.13)$ & $0.09(0.07)$ & $0.06(0.06)$ \\
\hline Partisan Commission & $0.06(0.13)$ & & $0.06(0.07)$ & \\
\hline Region & $-0.02(0.04)$ & & $0.01(0.02)$ & \\
\hline \multicolumn{5}{|l|}{ Political Orientation } \\
\hline Democrat & $0.06(0.12)$ & & $0.03(0.07)$ & \\
\hline Republican & $0.02(0.11)$ & & $0.07(0.07)$ & \\
\hline Ideology & $0.01(0.04)$ & & $-0.03(0.02)$ & $-0.03(0.02)$ \\
\hline In Party & $0.32(0.16)^{*}$ & $0.33(0.11)^{*}$ & $0.09(0.09)$ & \\
\hline Out Party & $-0.02(0.15)$ & & $0.05(0.09)$ & \\
\hline \multicolumn{5}{|l|}{ Political (Dis)taste } \\
\hline Congress Approval & $-0.09(0.04)^{*}$ & $-0.09(0.04)^{*}$ & $-0.07(0.02)^{*}$ & $-0.07(0.02)^{*}$ \\
\hline Pres. Approval & $-0.08(0.04)$ & $-0.07(0.03)^{*}$ & $0.03(0.05)$ & \\
\hline \multicolumn{5}{|l|}{ Awareness } \\
\hline Heard of Debate & & & $0.03(0.03)$ & \\
\hline$R^{2}$ & .17 & .16 & .07 & .06 \\
\hline$N$ & 537 & 537 & 1,155 & 1,155 \\
\hline
\end{tabular}

Dependent variables are ordered. For the first column, coded responses are "Yes" (equal to 1), "Not sure" or "No opinion" (equal to 0), "No" (equal to -1). For the second, coded responses are "Satisfied" (equal to 1), "Don't Know/Refuse" or "No opinion about it" (equal to 0), and "Dissatisfied" (equal to -1). Coefficients are from linear regressions to facilitate interpretation, but order probits were also run. Coefficients are significantly different from zero at $* p<.05$. 
Table B4. Questions Regarding Courts and Line-Drawing Authority (With Bias Data)

\begin{tabular}{|c|c|c|c|c|}
\hline \multirow[b]{2}{*}{ Variables } & \multicolumn{2}{|c|}{ Courts' Job } & \multicolumn{2}{|c|}{ Preferred Authority } \\
\hline & Saturated & Pared down & Saturated & Pared down \\
\hline \multicolumn{5}{|l|}{ Demographics } \\
\hline White & $0.31(0.18)$ & $0.30(0.18)$ & $0.22(0.29)$ & $0.23(0.29)$ \\
\hline Black & $0.48(0.32)$ & $0.48(0.31)$ & $-0.12(0.43)$ & $-0.12(0.43)$ \\
\hline Hispanic & $0.50(0.23)$ & $0.49(0.22) *$ & $-0.16(0.39)$ & $-0.11(0.37)$ \\
\hline Female & $0.05(0.10)$ & $0.05(0.09)$ & $-0.17(0.15)$ & $-0.18(0.15)$ \\
\hline Age & $-0.01(0.00)$ & $-0.01(0.00)^{*}$ & $0.00(0.01)$ & \\
\hline Education & $-0.02(0.05)$ & & $0.16(0.08)$ & $0.14(0.08)$ \\
\hline Income & $-0.02(0.01)$ & $-0.03(0.01)^{*}$ & $0.06(0.02)^{*}$ & $0.06(0.02)^{*}$ \\
\hline \multicolumn{5}{|l|}{ Geographic Variables } \\
\hline Recent Issue State & $-0.25(0.15)$ & $-0.18(0.10)$ & $-0.32(0.22)$ & $-0.24(0.17)$ \\
\hline Split State & $-0.13(0.17)$ & & $-0.03(0.25)$ & \\
\hline State Bias & $-0.06(0.17)$ & & $0.62(0.26)^{*}$ & $0.65(0.23)^{*}$ \\
\hline Commission & $0.24(0.18)$ & $0.23(0.11) *$ & $0.54(0.29)^{*}$ & $0.58(0.27) *$ \\
\hline Courts & $0.04(0.21)$ & & $-0.12(0.28)$ & \\
\hline Partisan Commission & $0.14(0.18)$ & & $0.74(0.27)^{*}$ & $0.69(0.25)^{*}$ \\
\hline Region & $0.00(0.05)$ & & $0.05(0.08)$ & \\
\hline \multicolumn{5}{|l|}{ Political Orientation } \\
\hline Democrat & $0.15(0.17)$ & & $0.10(0.25)$ & \\
\hline Republican & $0.16(0.16)$ & & $0.09(0.24)$ & \\
\hline Ideology & $0.00(0.06)$ & & $-0.04(0.09)$ & \\
\hline In Party & $-0.20(0.23)$ & & $-0.46(0.32)$ & $-0.41(0.22)$ \\
\hline Out Party & $-0.31(0.20)$ & $-0.17(0.13)$ & $-0.01(0.32)$ & \\
\hline \multicolumn{5}{|l|}{ Political (Dis)taste } \\
\hline Congress Approval & $-0.11(0.06)$ & $-0.09(0.05)$ & $0.12(0.08)$ & $0.12(0.08)$ \\
\hline Pres. Approval & $0.05(0.06)$ & & $0.20(0.09)^{*}$ & $0.22(0.07)^{*}$ \\
\hline Log Likelihood & & & -284.8 & -286.1 \\
\hline Pseudo $R^{2}$ & & & .12 & .12 \\
\hline$R^{2}$ & .08 & .07 & & \\
\hline$N$ & 537 & 537 & 490 & 490 \\
\hline
\end{tabular}

Dependent variables are ordered or binary. For the first column, coded responses are "Very Good" (equal to 2), "Good" (equal to 1), "Not sure" (equal to 0), "Poor" (equal to -1), and "Very Poor" (equal to -2). Coefficients are from linear regressions to facilitate interpretation but order probits were also run. For the second, coded responses are "Commission" (equal to 1) and "Legislature" or "Not Sure" (equal to 0). "No opinion" responses are excluded. Probit regressions were run on this binary variable. Coefficients are significantly different from zero at $* p<.05$. 